\title{
SELF EFFICACY ADOLESCENTS IN PREVENTION OF RISKY BEHAVIOR OF DRUG ABUSE IN BALUNG JUNIOR HIGH SCHOOL
}

\author{
Ginanjar Sasmito Adi 1), Ratih Aprilita Wulandari 2) \\ 1)Lecture of Faculty of Health Science University of Muhammadiyah Jember \\ 2)Student of Faculty of Health Science University of Muhammadiyah Jember \\ Corresponding e-mail : ginanjarsasmitoadi@unmuhjember.ac.id
}

\begin{abstract}
BACKGROUND : Drug abuse is a problem that must be solved because it is related to the future of the nation in this case is teenagers. Prevention of drug abuse can be done from within adolescents through increasing self-efficacy (self-confidence) to take preventive drug abuse measures. This study aims to identify adolescent self-efficacy in the prevention of drug abuse in Balung Junior High School.

SUBJECT AND METHODE : This research is a descriptive analytic study with 77 samples.

RESULTS : Result of this research found self efficacy variable the majority showed high self efficacy by 42 respondents (54.4\%) and others showed moderate self efficacy by $45.5 \%$. In risk behavior, it is found that there are mostly risk behaviors among respondents, namely 64 respondents (83.1\%) and only 13 respondents (16.9\%) who are not at risk.

CONCLUSION : Recommendation of this study To the parties involved in this case are the family, school, health workers, government, law enforcement and other parties there needs to be an increase in the socialization of increasing understanding of youth in preventing drug abuse
\end{abstract}

Key Word : Adolocent, drug abuse, self efficacy

\section{INTRODUCTION}

The problem of drug abuse (narcotics, psychotropic substances and other addictive substances) is a complex problem and causes losses that cover various aspects and are related to the future of the nation. Although the prevalence of drug abuse tends to decrease in the last 10 years, both for use and a year of use. In 2016, there were an estimated 167 to 315 million people worldwide (around $5.6 \%$ of the world's population aged 15-64 years) who had abused drugs at least once. The prevalence rate ever used decreased from $8.1 \%$ (2006) to $3.8 \%$ (2016) Or it can be interpreted, if in 2006 there were 8 out of 100 students who used drugs then now there are only 4 people who use drugs in in 2016). (Badan Narkotika Nasional Republik Indonesia \& Pusat Penelitian Kesehatan Universitas Indonesia, 2017)

The large number of drug abuse cases becomes an important source to pay attention to adolescents as those who are at risk of drug abuse. Nearly $36 \%$ of adolescents are at risk of drug abuse.(Purwandari, 2015). Behavior risk of drug abuse is influenced by other behaviors that can be a stimulus that affects drug abuse such as smoking, drinking alcohol and premarital sex (Badan Narkotika Nasional Republik Indonesia \& Pusat Penelitian Kesehatan Universitas Indonesia, 2017) 
Based on the literature review risk behavior in adolescents is influenced by knowledge, attitudes, age, sex, education, economic status, access to information media, communication with parents and the presence of friends who behave risky (Muslihatun \& Santi, 2015). Factors of drug abuse by adolescents come from individual factors (internal), family factors and peer factors. Adverse influences from the social environment, especially the influence and pressure of a group of peers often become a source of causes of drug abuse. The peer group serves as the initial media for introductions to narcotics (Afiatin, 1998).

Risk behaviors in adolescents can also be caused by negative psychological attributes such as self-esteem and low efficacy and loss of ability to control health. (Arifa Insani Anggai, 2015). Efficacy plays a very important role in daily life, a person will be able to use his potential optimally if self-efficacy supports it. Self-efficacy is a belief in a person to be sure of being able and successful in doing something until the final goal is reached. Self-efficacy has a strong relationship with risky behavior, one of which is drug abuse (Rustika, 2016; Wilandika, 2017)

Based on the description above, the researcher wants to identify how self-efficacy in adolescents in preventing risk behavior of drug abuse in Balung Junior High School Jember

\section{METHODE}

This research is descriptive analytic. The population in this study were 130 respondents in Balung Middle School. The sample size in this study was 77 respondents taken using simple random sampling technique. Data collection instruments used in this study were self-efficacy questionnaire and risk behavior questionnaire. The risk behavioral questionnaire consists of 10 questions Is your residence very close to drugs? Do you like to hang out with drug addicts? Do you have a smoking habit? Do you make smoking as a stress reliever? Do you like to hallucinate? Do you have bad habits to increase your confidence? Have you ever seen a form of drugs? Do you always spend time hanging out with friends without clear goals? Have you ever been offered to try drugs? Did you ever intend to try drugs? The self-efficacy instrument consisted of 26 questions with a Likert scale.

\section{RESULT AND DISCUSSION}

Table 1. Distribution of Characteristics of Respondents from students of Balung Junior High School $(n=77)$

\begin{tabular}{lll}
\hline Characteristics & Total & Prosentase \\
\hline Age & & \\
12 & 2 & 2.6 \\
13 & 4 & 5.2 \\
14 & 56 & 72.7 \\
15 & 15 & 19.5 \\
Gender & & \\
Boy & 27 & 35.1 \\
Girl & 50 & 64.9 \\
Type of Residence & & \\
With Both Parent & 73 & 94.8 \\
One Parent & 1 & 1.3 \\
Alone & 3 & 3.9 \\
\hline
\end{tabular}




\begin{tabular}{lll}
\hline $\begin{array}{l}\text { Parent marital Status } \\
\text { Maried }\end{array}$ & 75 & 97.4 \\
widower / widow died & 1 & 1.3 \\
$\quad$ widower / widow alive & 1 & 1.3 \\
Father's occupation & 13 & \\
PNS & 46 & 59.9 \\
Entrepreneur & 12 & 15.6 \\
Private & 6 & 7.8 \\
$\quad$ Farmer & 11 & 14.3 \\
Mother's occupation & 39 & 50.6 \\
PNS & 20 & 26.0 \\
Entrepreneur & 7 & 9.1 \\
Private & & \\
Farmer & 5 & 6.5 \\
father's education & 14 & 18.2 \\
$\quad$ Elementary School & 40 & 51.9 \\
$\quad$ Junior High School & 18 & 23.4 \\
Senior High School & & \\
Collage & 6 & 7.8 \\
Mother's education & 16 & 20.8 \\
Elementary School & 34 & 44.2 \\
Junior High School & 21 & 27.3 \\
Senior High School & & \\
Collage &
\end{tabular}

Based on the results of the study found that most risk behaviors are risk behaviors among respondents, as many as 64 respondents (83.1\%) and only 13 respondents (16.9\%) who are not at risk. Respondent's risk behavior in this study shows a high number this can be caused because the respondent is said to be at risk if it intersects with 1 condition out of 10 questions.

Based on the analysis of the National Narcotics Agency smoking, alcohol and free sex become one of the triggers in drug abuse. (Badan Narkotika Nasional Republik Indonesia \& Pusat Penelitian Kesehatan Universitas Indonesia, 2017). In addition, risk behaviors that affect the level of risk of narcotics use are smoking, visiting nightlife, hangout behavior, school attendance behavior and alcoholic drinks.(Azmiardi, Taufik, \& Abrori, 2015)

Based on research conducted by afandi (2009) Factors that influence drug abuse are gender, residence, marital status of parents, academic achievement, smoking habits, smoking friends, peer group members and extracurricular activities. The involvement of free time activities as an effective mediator becomes a position between the school's commitment to risk behavior for drug abuse. This means that the involvement of positive free time activities must be carried out among adolescents and well managed so that the commitment of the school as a social control institution is able to function properly to prevent risk behaviors of drug abuse (Purwandari, 2015). Based on this research the characteristics of the respondents most teenagers live with parents, where control is still exercised by parents. Only a small proportion of families get divorced so that parents' love or attention is gained by teenagers. Both parents' knowledge is high with an average high school and 
above. Although supported by the characteristics of respondents as above, communication and attachment in the family are not reflected in this study so that it can be confounding in this study.

According to Nevid, dkk. (1997) in (Afiatin, 1998) drug abuse is very closely related to the role of a number of factors that involve cognitive factors such as expectations and beliefs about drugs, the decision making process and self-awareness. Expectations and beliefs about drugs are greatly influenced by individual knowledge about drug problems. Adolescents who have drug knowledge about the negative effects of drugs, so they tend to have positive hopes and beliefs and this makes teens have a tendency to use drugs to be smaller.

Table 2. Distribution of self efficacy variables and risk behaviors among students of Balung Junior High School $(n=77)$

\begin{tabular}{ccc}
\hline Variabel & Total & Persentase \\
\hline Self Efficacy & & \\
Moderate & 35 & 45.5 \\
High & 42 & 54.5 \\
\hline Risk Behavior & & \\
Risk & 64 & 83.1 \\
No Risk & 13 & 16.9 \\
\hline
\end{tabular}

In addition to hopes and beliefs, the influence of individual beliefs is also very important in drug abuse. Teenagers who doubt their ability to be easily attracted to drug abuse will be easily attracted to be able to change their conditions. The appeal of adolescents to drugs lies in their ability to increase self-efficacy expectations, both directly, for example by increasing feelings of being more powerful, stronger, and more prosperous; or indirectly, for example by reducing feelings of anxiety and stress.(Afiatin, 1998)

Based on the results of the analysis of the efficacy of adolescents in this study showed selfefficacy in the majority of respondents showed a high self-efficacy of 42 respondents (54.4\%) and moderate self-efficacy of $45.5 \%$. While the results of research on risk behavior, there are mostly risk behaviors among respondents, as many as 64 respondents (83.1\%) and only 13 respondents $(16.9 \%)$ who are not at risk. Efficacy plays a very important role in daily life, a person will be able to use his potential optimally if self-efficacy supports it.(Rustika, 2016)

In this study the division of self efficacy into 3 is high, medium and low. The results showed that there were no respondents who showed low self efficacy. This is caused in social cognitive theory, low self-efficacy will cause increased anxiety and avoidance behavior. Individuals will avoid activities that can worsen the situation, this is not caused by threats but because they feel they do not have the ability to manage aspects of risk (Rustika, 2016).

According to Schwarzer dan Renner (1995) there are 3 dimensions that describe a person's self-efficacy. The first dimension is the belief to persevere, in the form of a belief in continuing to carry out tasks in all situations and conditions. The second dimension is the belief to increase ability in the form of belief to be able to learn certain abilities in all situations and conditions. The third dimension is the belief to control oneself in the form of beliefs still perform positive behaviors despite the relatively large challenges faced, the belief to be able to learn all the abilities to avoid risky behavior, and the confidence to control oneself from risky behavior despite internal and external pressure is 
very strong. Self-efficacy has a positive correlation with risk behaviors in adolescents, although in this study the dominance of high self-efficacy is not supported by risk behaviors that are raised by adolescents. Most adolescents have the risk to get into drug abuse (Wilandika, 2017)

Adolescents can avoid risky behavior if adolescents are embedded in self-efficacy to prevent risky behavior. High self-efficacy in adolescents makes adolescents have the personal confidence to keep behaving healthy despite the tough challenges. Self-efficacy makes teenagers also have the confidence to be able to learn all the abilities to avoid risky behavior. Self-efficacy is an individual's evaluation of his ability or competence to complete a task, achieve goals, or face a challenge. Individuals who have high self-efficacy will be able to motivate themselves and control the surrounding environment so that they can display certain behaviors as they wish.

\section{CONCLUSION AND RECOMMENDATION}

In the self efficacy variable the majority showed high self efficacy by 42 respondents (54.4\%) and others showed moderate self efficacy by $45.5 \%$. In risk behavior, it is found that there are mostly risk behaviors among respondents, namely 64 respondents (83.1\%) and only 13 respondents $(16.9 \%)$ who are not at risk.

To the parties involved in this case are the family, school, health workers, government, law enforcement and other parties there needs to be an increase in the socialization of increasing understanding of youth in preventing drug abuse

\section{REFERENCES}

Afiatin, T. (1998). Bagaimana Menghindarkan Diri Dari Penyalahgunaan Napza. Buletin Psikologi, 6(2), 27-39. https://doi.org/10.22146/bpsi.7396

Arifa Insani Anggai. (2015). HUBUNGAN ANTARA EFIKASI DIRI DENGAN PERILAKU BERISIKO TERHADAP KESEHATAN PADA REMAJA (Universitas Muhammadiyah Surakarta; Vol. 151). https://doi.org/10.1145/3132847.3132886

Azmiardi, A., Taufik, M., \& Abrori. (2015). PERILAKU BERISIKO YANG MEMPENGARUHI TINGKAT RISIKO PENGGUNAAN NARKOTIKA PADA SISWA SMKN 1 SINGKAWANG. 49.

Badan Narkotika Nasional Republik Indonesia, \& Pusat Penelitian Kesehatan Universitas Indonesia. (2017). Ringkasan Eksekutif Hasil Survei BNN Tahun 2016.

Muslihatun, W. N., \& Santi, M. Y. (2015). Antisipasi Remaja Terhadap Bahaya Penyalahgunaan Narkoba Dalam Triad Kesehatan Reproduksi Remaja Di Sleman. Jurnal Kebidanan Dan Keperawatan, 11(1), 41-50.

Purwandari, E. (2015). Model Kontrol Sosial Perilaku Remaja Berisiko Penyalahgunaan NAPZA. Desertasi Program Doktor Psikologi Fakultas Psikologi UGM Tahun 2015. Https://Repository.Ugm.Ac.Id/136739/1/2015_2015_eny_purwandari_mn.Pdf. Retrieved from https://repository.ugm.ac.id/136739/1/2015_2015_eny_purwandari_mn.pdf 
Rustika, I. M. (2016). Efikasi Diri: Tinjauan Teori Albert Bandura. Buletin Psikologi, 20(1-2), 18-25. https://doi.org/10.22146/bpsi.11945

Wilandika, A. (2017). ANALISIS FAKTOR INSTRUMEN EFIKASI DIRI PENCEGAHAN PERILAKU BERISIKO HIV. 